\title{
Biological Maturity of Injuries Sustained due to Causes among Football Players
}

Singh, Shinku Kumar, Assistant Professor, Department of Physical Education, Swami Ramanand Teerth Marathwada University, Nanded Maharashtra India email: shantanu.halder93@gmail.com

\section{Abstract}

The primary aim of the present study was to compare the incidence of injuries sustained due to causes among three groups of competitive football players. The investigator has made an attempt to classify or define the groups of football players based on the aged of the football players. Accordingly three groups of football players were targeted; Junior, Young and Senior groups football players aged between 14 to 30 years. The investigator personally contacted the players and the purpose of the study was explained to them. Further instructions were given by the investigator to the players for the completion of questionnaire. A questionnaire prepared by Cromwell \& Gromely (2000) for elite Gaelic football players and modified by the investigator was used. The information of injuries was collected from 685 elite football players of three groups. Total 480 injuries out of 388 football players were found out over the one year of the period. Means, Standard deviations, one way analysis of variance and post hoc test were utilized to compare the incidence of injuries among three groups of football players. The result reveals that there was statistically significant difference of incidence of injuries with respect to causes found in Stumble ( $\mathrm{F}=6.68,<.05)$ and Tackle ( $\mathrm{F}=13.30,<.05)$ However, there were insignificant difference of incidence of injuries found in Collision $(\mathrm{F}=.90)$, Running $(\mathrm{F}=.1 .25)$, Contact with Ball $(\mathrm{F}=1.93)$, Foul play $(\mathrm{F}=0.25)$, Twist $(\mathrm{F}=2.23)$ and Kicking the Ball $(\mathrm{F}=0.75)$.

Key words: Health related physical fitness, reaction ability, Rural, Urban

\section{Introduction}

Football is a high risk sport dominated by overuse injuries while recovery time from injuries is relatively long, but only a few working days are lost by the players to return back to play, thus leading to abuse of the injured sites. In football only a few studies have been made in the literature regarding incidents of injury and pattern, possible risk factors and injury prevention (Griffith, 1989; Wastan, 1993; Junge, 2000). In football overuse injuries are the most frequent incidences of injury; and injuries are traditionally divided into contact and non contact causes in which case contact refers to players contact. Some of the forces involved in a non contact injury are transmitted from the playing surface to the injured body part. (Orchard et al, 2001)

Injuries in football normally occur due to physical contacts. Even though injuries in football are driven by several factors, factors such as the physical and the lack and/or improper physical preparation, the violence and harsh playing style of the opponents, Injuries in sport activities can occur for many reasons such as stumble, tackle, running, foul play and collision. (Cromwell \& Gromely, 2000) No matter how safe the environment or how well conditioned the athlete is will sometimes inevitably produce some 
injuries, whether it is by contact with other bodies or by psychological factors as reported in various studies. Soccer entails physical contact in the course of tackling or contesting possession of the ball with opponents and this inevitably leads to injury of varying severity. A majority of injuries are unintentional, resulting from an error may lead to an accident and some of these accidents lead to injuries. The present study deals with comparison of injuries accoroding to biological maturity among three groups of competitive football players. The investigator has made an attempt to classify the football players based on the aged group.

\section{Materials and Methods}

Keeping in view the objective of the study, three groups of football players were targeted. Junior, young and senior group football players aged between 14 to 30 years. The data was collected with the help of questionnaires reported by Cromwell \& Gromely, (2000) for Elite Gaelic football players. The subjects were required to fill out a questionnaire for each injury for one year. The information of injuries was collected from 685 football players of three groups and a total of 480 injuries out of 388 football players were found out over the period of one year to explore and measure the injuries incidence in the three group of football players. The groups are junior (aged14-18), Young (aged19-24) and senior (aged 25-30) groups football players. This study aims to compare the Injuries among these three groups who are playing in the same sports. Research Design: The design in a research study refers to "the researcher's overall plan for answering the researcher's question or testing the research hypotheses. This study involves a comparative survey of three groups of football players in a non-experimental, retrospective study design.

Statistical analysis: The Statistical Package for the Social Sciences (SPSS; version 18.0) was used for the data analysis. One Way Analysis of Variance and post hoc test were used to assess overall differences of injuries among three groups.

\section{Results \& Discussion}

Table-1: Mean scores and Standard Deviations of incidence of injuries with respect to causes among three groups of football players

\begin{tabular}{|c|c|c|c|c|c|}
\hline $\begin{array}{l}\text { Sr. } \\
\text { No }\end{array}$ & Causes & $\begin{array}{l}\text { Football } \\
\text { players }\end{array}$ & $\mathbf{N}$ & $\begin{array}{l}\text { Mean } \\
\text { Score }\end{array}$ & SD \\
\hline \multirow{3}{*}{1} & \multirow{3}{*}{ Collision } & Young & 22 & 1.18 & 0.39 \\
\hline & & Junior & 35 & 1.05 & 0.35 \\
\hline & & Senior & 08 & 1.12 & 0.37 \\
\hline \multirow{3}{*}{2} & \multirow{3}{*}{ Foul Play } & Young & 39 & 1.10 & 0.36 \\
\hline & & Junior & 41 & 1.17 & 0.39 \\
\hline & & Senior & $\mathbf{0 3}$ & 1.00 & 0.32 \\
\hline \multirow{3}{*}{3} & \multirow{3}{*}{ Running } & Young & 39 & 1.25 & 0.41 \\
\hline & & Junior & 33 & 1.12 & 0.37 \\
\hline & & Senior & 05 & 1.00 & 0.32 \\
\hline \multirow{3}{*}{4} & \multirow{3}{*}{$\begin{array}{l}\text { Contact } \\
\text { with Ball }\end{array}$} & Young & 13 & 1.46 & 0.48 \\
\hline & & Junior & 16 & 1.06 & 0.35 \\
\hline & & Senior & 02 & 1.00 & 0.32 \\
\hline \multirow{3}{*}{5} & \multirow{3}{*}{$\begin{array}{l}\text { Stumblin } \\
\text { g }\end{array}$} & Young & 17 & 1.50 & 0.38 \\
\hline & & Junior & 19 & 1.10 & 0.36 \\
\hline & & Senior & 08 & 1.00 & 0.32 \\
\hline \multirow{3}{*}{6} & \multirow{3}{*}{$\begin{array}{l}\text { Tackl- } \\
\text { ing }\end{array}$} & Young & 27 & 1.18 & 0.39 \\
\hline & & Junior & 19 & 1.10 & 0.36 \\
\hline & & Senior & 06 & 1.00 & 0.32 \\
\hline \multirow{3}{*}{7} & \multirow{3}{*}{ Twisting } & Young & 09 & 1.11 & 0.37 \\
\hline & & Junior & 12 & 1.00 & 0.32 \\
\hline & & Senior & 02 & 1.00 & 0.32 \\
\hline \multirow{3}{*}{8} & \multirow{3}{*}{$\begin{array}{l}\text { Ball } \\
\text { Kick-ing }\end{array}$} & Young & 23 & 1.13 & 0.37 \\
\hline & & Junior & 15 & 1.00 & 0.32 \\
\hline & & Senior & 03 & 1.00 & 0.32 \\
\hline
\end{tabular}

Table-1, indicates the mean scores and standard deviations of incidence of injuries due to causes among three groups of competitive football players.

The mean scores (S.Ds.) of injuries sustained due to Collision of young football players were $1.18(0.39)$, junior group football players were 1.05 (0.35) and senior group football players 
were $1.12(0.37)$. The mean scores (S.Ds.) of injuries sustained due to Foul Play of young football players were 1.10 (0.36), junior group football players were 1.17 (0.39) and senior group football players were $1.00(0.32)$. The mean scores (S.Ds.) of injuries sustained due to Running of young football players were 1.25 (0.41), junior football players were $1.12(0.37)$ and senior football players were 1.00 (0.32). The mean scores (S.Ds.) of injuries sustained due to Contact with Ball to young group football players were 1.46 (0.48), junior group football player were $1.06(0.35)$ and senior group football players were 1.00 (0.32). The mean scores (S.Ds.) of injuries sustained due to Stumble of young group football players were $1.50(0.38)$, junior football players were $1.10(0.36)$ and senior football players were 1.00 (0.32). The mean scores (S.Ds.) of injuries sustained due to Tackle of young football players were 1.18(.39), junior football players were $1.10(.36)$ and senior football players were $1.00(.32)$. The mean scores (S.Ds.) of injuries sustained due to Twist of young football players were 1.11(0.37), junior football players were $1.00(0.32)$ and senior football players were 1.00 (0.32) and the mean scores (S.Ds.) of injuries sustained due to Kicking the Ball of young football players were 1.13 (0.37), junior football players were 1.00 (0.32) and senior football players were 1.00 (0.32).

In order to find out the significant difference of incidence of injuries among three groups of competitive football players; ANOVA was applied the results of which are presented in Table 2.
Table - 2: One way Analysis of Variance of incidence of injuries sustained due to causes among three groups of

\begin{tabular}{|c|c|c|c|c|c|c|}
\hline $\begin{array}{l}\text { Sr. } \\
\text { No. }\end{array}$ & Causes & $\begin{array}{c}\text { Source } \\
\text { of } \\
\text { Variance }\end{array}$ & DF & SS & MSS & $\begin{array}{c}\text { F- } \\
\text { ratios }\end{array}$ \\
\hline \multirow[t]{2}{*}{1.} & \multirow[t]{2}{*}{ Collision } & $\begin{array}{c}\text { Between } \\
\text { groups }\end{array}$ & 02 & 0.20 & 0.10 & \multirow[t]{2}{*}{$0.90^{\mathrm{NS}}$} \\
\hline & & $\begin{array}{l}\text { Within } \\
\text { groups }\end{array}$ & 62 & $\begin{array}{c}07.0 \\
4 \\
\end{array}$ & 0.11 & \\
\hline \multirow[t]{2}{*}{2.} & \multirow{2}{*}{$\begin{array}{l}\text { Foul } \\
\text { Play }\end{array}$} & $\begin{array}{c}\text { Between } \\
\text { groups }\end{array}$ & 02 & 0.15 & 0.07 & \multirow[t]{2}{*}{$0.25 \mathrm{NS}$} \\
\hline & & $\begin{array}{l}\text { Within } \\
\text { groups }\end{array}$ & 80 & $\begin{array}{c}23.3 \\
5\end{array}$ & 0.29 & \\
\hline \multirow[t]{2}{*}{3.} & \multirow[t]{2}{*}{ Running } & $\begin{array}{c}\text { Between } \\
\text { groups }\end{array}$ & 02 & 0.50 & 0.25 & \multirow[t]{2}{*}{$1.25 \mathrm{NS}$} \\
\hline & & $\begin{array}{l}\text { Within } \\
\text { groups }\end{array}$ & 74 & $\begin{array}{c}14.9 \\
6\end{array}$ & 0.20 & \\
\hline \multirow[t]{2}{*}{4.} & \multirow{2}{*}{$\begin{array}{l}\text { Contact } \\
\text { with Ball }\end{array}$} & $\begin{array}{l}\text { Between } \\
\text { groups }\end{array}$ & 02 & & & \multirow[t]{2}{*}{$1.93^{\mathrm{NS}}$} \\
\hline & & $\begin{array}{l}\text { Within } \\
\text { groups }\end{array}$ & 28 & 9.16 & 0.32 & \\
\hline \multirow[t]{2}{*}{5.} & \multirow[t]{2}{*}{ Stumble } & $\begin{array}{l}\text { Between } \\
\text { groups }\end{array}$ & 02 & 2.14 & & \multirow[t]{2}{*}{$6.68 *$} \\
\hline & & $\begin{array}{l}\text { Within } \\
\text { groups }\end{array}$ & 41 & 6.94 & 0.16 & \\
\hline \multirow[t]{2}{*}{6.} & \multirow[t]{2}{*}{ Tackle } & $\begin{array}{l}\text { Between } \\
\text { groups }\end{array}$ & 02 & 6.92 & 3.46 & \multirow[t]{2}{*}{$13.30 *$} \\
\hline & & $\begin{array}{l}\text { Within } \\
\text { groups }\end{array}$ & 44 & $\begin{array}{c}11.8 \\
6 \\
\end{array}$ & 0.26 & \\
\hline \multirow[t]{2}{*}{7.} & \multirow{2}{*}{$\begin{array}{l}\text { Kicking } \\
\text { the Ball }\end{array}$} & $\begin{array}{c}\text { Between } \\
\text { groups }\end{array}$ & 02 & 0.18 & .09 & \multirow[t]{2}{*}{$0.75^{\mathrm{NS}}$} \\
\hline & & $\begin{array}{l}\text { Within } \\
\text { groups }\end{array}$ & 38 & 4.60 & 0.12 & \\
\hline \multirow[t]{2}{*}{8} & \multirow[t]{2}{*}{ Twist } & $\begin{array}{c}\text { Between } \\
\text { groups }\end{array}$ & 02 & 0.28 & 0.14 & \multirow[t]{2}{*}{$2.23 \mathrm{NS}$} \\
\hline & & $\begin{array}{l}\text { Within } \\
\text { groups }\end{array}$ & 20 & 1.24 & 0.06 & \\
\hline
\end{tabular}

* Significant at .05 level, NS = Not Significant

Table 2 shows the, Analysis of Variance of incidence of injuries sustained due to causes among three groups of football players. In order to find out the difference of incidence of injuries with respect to causes among three groups of competitive football players. F-ratio was computed for each cause separately. The data given in Table 2 shows that there was statistically significant difference of incidence of injuries with respect to causes found in Stumble $(\mathrm{F}=6.68,<.05)$ and Tackle ( $\mathrm{F}=13.30,<.05)$ However, there were insignificant difference of incidence 
of injuries found in Collision $(\mathrm{F}=.90)$, Running $(\mathrm{F}=.1 .25)$, Contact with Ball $(\mathrm{F}=1.93)$, Foul play $(\mathrm{F}=0.25)$, Twist $(\mathrm{F}=2.23)$ and Kicking the Ball $(\mathrm{F}=0.75)$.

In order to locate the incidence of injuries due to stumble among three groups of competitive football players; Scheffe post hoc test was applied to compare the incidence of injuries; Table 3 shows the possible comparisons for three group means.

Table - 3: Scheffe post hoc Statistically Comparison for mean difference of incidence of injuries due to stumble among three groups of competitive football players.

\begin{tabular}{ccccc}
\hline \multicolumn{3}{c}{ Mean Scores } & & \\
\hline Junior & Young & Senior & $\begin{array}{c}\text { Mean } \\
\text { difference }\end{array}$ & $\begin{array}{c}\text { C.D. } \\
\text { at 5\% } \\
\text { level }\end{array}$ \\
1.10 & 1.50 & & 0.40 & 0.42 \\
1.10 & & 1.00 & 0.10 & 0.36 \\
& 1.50 & 1.00 & 0.50 & $0.42 *$ \\
\hline
\end{tabular}

* Significant at .05 level.

Table 3, reveals that insignificant difference of incidence of injuries was found between junior and young group football players sustained due to stumble. (ii) Insignificant difference of incidence of injuries sustained due to stumble was found between junior and senior group football players. (iii) Significant difference of incidence of injuries sustained due to stumble was found between young and senior group football players. Young group football players reported maximum injuries sustained due to tackle as compare than senior football players.

As per Table 4, shows that the Scheffe post hoc statistical comparison for mean difference of incidence of injuries due to tackle among three groups of competitive football players.

Table: 4: Scheffe post hoc Statistically Comparison for mean difference of incidence of injuries sustained due to tackling among the three groups of competitive football players.

\begin{tabular}{ccccc}
\hline \multicolumn{3}{c}{ Mean Scores } & & \\
\hline Junior & Young & Senior & $\begin{array}{c}\text { Mean } \\
\text { difference }\end{array}$ & $\begin{array}{c}\text { C.D. } \\
\text { at 5\% } \\
\text { level }\end{array}$ \\
\hline 1.10 & 1.18 & & 0.08 & .16 \\
1.10 & & 1.00 & 0.10 & .18 \\
& 1.18 & 1.00 & 0.18 & $.17 *$ \\
\hline
\end{tabular}

* Significant at .05 level.

Table 4, reveals that (i) No statistically significant difference of incidence of injuries was found between junior and young groups football players sustained due to tackling. (ii) No Statistically significant difference of incidence of injuries sustained due to tackle was found between junior and senior groups football players. (iii) Significant difference of incidence of injuries sustained due to tackling was however found between young and senior groups football players. Young group of football players reported greater injuries sustained due to tackling as compared to the senior football players.

\section{Discussion}

Injury is a common phenomenon in the game of football. Injuries can occur in football even though everything possible is done to reduce the factors that might cause injuries. This study reveals that those football players who are directly involved in attack and defence are more likely to get injured and this study support the findings reported earlier by Sinku (2006) and Crombell (2000) who also reported that those football players who are directly involved in attack or defense are more likely to be injured.

Injuries that occur in contact with another player are common in football. Most of these situations occur when two or more players try to win the ball at the same time, or a player attempts to win the ball from an opponent. There are a large 
number of studies that report the influence of foul play on injury rate (Ekstrand et al, 1983b; Nielsen and Yde, 1989; Engstrom et al, 1990; Hawkins and Fuller, 1996; Luthje et al, 1996;Hawkins and Fuller, 1998b; Hawkins and Fuller, 1999, Chomiak et al, 2000; Junge et al, 2000a). Results have shown that foul play is the cause of 16-28\% of all injuries (Nielsen and Yde, 1989; Hawkins and Fuller, 1996; Hawkins and Fuller, 1999; Junge et al, 2000a), or $28-30 \%$ of traumatic injuries (Ekstrand and Gillquist, 1983b; Engstrom et al, 1990). Other studies have reported that $76-86 \%$ of the foul play injuries are caused by opponent and the rest by own foul (Ekstrand and Gillquist, 1983b; Hawkins and Fuller, 1999), and also reported that own foul play resulted in more serious injuries than opponent foul (Ekstrand and Gillquist, 1983b). In elite players contact injuries represents for 33$42 \%$ of all acute injuries (Hawkins and Fuller, 1999; Hawkins et al, 2001). Only Luthje et al (1996) found much higher proportion of contact injuries (79\%). Studies on players at lower or various level reports that $55-59 \%$ of acute injures were contact injuries, while the comparable percentage for junior players was $42-53 \%$ (Ekstrand and Gillquist, 1983a; Nielsen and Yde, 1989; Hawkins and Fuller, 1999; Ostenberg and Roos, 2000; Heidt, Jr. et al. 2000). Tackling is the most common injury mechanism in football (Nielsen and Yde, 1989, Luthje et al, 1996; Hawkins and Fuller, 1999). Studies on elite players have indicated that tackling is responsible for $21-39 \%$ of acute injuries (Luthje et al. 1996; Hawkins and Fuller 1999), while for junior players this rate is $40-48 \%$ (Nielsen and Yde, 1989; Yde and Nielsen, 1990; Hawkinsand Fuller, 1999). Studies have also indicated that tackling is the most usual injury mechanism for ankle (43$67 \%$ ) and knee (55\%) injuries (Nielsen and Yde, 1989; Yde and Nielsen, 1990).

Few studies (Sinku, 2006, 2009, \& Pagare, 2009) show that collision is the most usual mechanism for concussion, and such collisions account for an even larger proportion of concussions in female players $(71-75 \%)$ than in males (47-65\%) (Barnes et al, 1998; Boden et al, 1998). Of these, head-to-head contact has been shown to be the most common mechanism (28\% of the total number of concussions), followed by head to elbow contact (14\%) (Boden et al, 1998). A larger proportion of collisions with other objects than players occurred among male players (35$53 \%$ ) than females (25-29\%) (Barnes et al, 1998; Boden et al, 1998), and most of them occurred when a player was hit in the head by the ball. Studies report that 58$67 \%$ of acute injuries in elite male football occurred in non-contact situations, while $41-45 \%$ of acute injuries in players at lower or various level and $47-58 \%$ of acute injuries in youth players occurred in non-contact situations (Ekstrand and Gillquist, 1983a; Nielsen and Yde, 1989; Hawkins and Fuller, 1999; Ostenberg and Roos, 2000; Heidt, Jr. et al, 2000; Chomiak et al, 2000; Hawkins et al, 2001). Running is the most usual noncontact injury mechanism, accounting for $20-24 \%$ of acute injuries in elite players and $9-27 \%$ in youth players (Yde and Nielsen, 1990; Hawkins and Fuller, 1999; Hawkins et al, 2001). Muscle strains occur most frequently 
during sprinting, especially hamstring strains (Nielsen and Yde, 1989). Kicking the ball has found to be the mechanism of $9-10 \%$ of acute injuries in elite players and $8-13 \%$ in youth players (Nielsen, 1990; Hawkins and Fuller, 1999). Finally, the most important usage of this research is to prevent the incidence of subsequent injuries by identifying injured athletes and to provide preventive strategies.

\section{References}

Boden, B.P., Kirkendall, D.T., and Garrett, W.E., Jr. 1998. Concussion incidence in elite college soccer players. Am. J. Sports Med., 26: $238-241$.

Chomiak, J., Junge, A., Peterson, L., and Dvorak, J. 2000. Severe injuries in football players. Influencing factors. Am. J. Sports Med., 28: S58-S68

Cromwell, F.J. Gromely, W. 2000. A Pilot Study examining injuries in elite gaelic football players. Br. J. Sports Med., 34: 104-108.

Ekstrand, J. and Gillquist, J. 1983a. Soccer injuries and their mechanisms: a prospective study. Med. Sci. Sports Exerc., 15: 267-270

Griffith, H.W. 1989. Complete guide to sports injuries. Motropolitan Book Co. (P).

Hawkins, R.D. and Fuller, C.W. 1996. Risk assessment in professional football: an examination of accidents and incidents in the 1994 World Cup finals. Br. J. Sports Med., 30: $165-170$.

Hawkins, R.D. and Fuller, C.W. 1998b. An examination of the frequency and severity of injuries and incidents at three levels of professional football. Br. J. Sports Med., 32: 326-332.

Hawkins, R.D. and Fuller, C.W. 1999. A prospective epidemiological study of injuries in four English professional football clubs.
Br. J. Sports Med., 33: 196-203

Heidt, R.S., Jr., Sweeterman, L.M., Carlonas, R.L., Traub, J.A., and Tekulve, F.X. 2000. Avoidance of soccer injuries with preseason conditioning. Am. J. Sports Med., 28: 659662.

Junge, A. 2000. The influence of psychological factors on sports injuries. Review of the literature. Am. J. Sports Med., 28: S10-S15.

Nielsen, A.B. and Yde, J. 1989. Epidemiology and traumatology of injuries in soccer. Am. $J$. Sports Med., 17: 803-807.

Orchard, J. 2001. The AFL penetrometer study: work in progress. J. Sci. Med. Sport, 4: 220232.

Orchard, J., Seward, H., McGivern, J., and Hood, S. 2001. Intrinsic and extrinsic risk factors for anterior cruciate ligament injury in Australian football players. Am. J. Sports Med., 29: 196-200.

Ostenberg, A. and Roos. H. 2000. Injury risk factors in female European football. A prospective study of 123 players during one season. Scand. J. Med. Sci Sports, 10: 279285.

Singh, Sinku Kumar 2004. A study of injuries prevalence in Aquatic players" An unpublished Master thesis. Banaras Hindu University, Varanasi.

Singh, Sinku Kumar 2006 " Injury prevalence in competitive swimmers" Ind. J. Sports Study, 6: $40-44$.

Singh, Sinku Kumar 2006. Comparison of occurrence of injuries to football players at low and high level of achievement. An unpublished M.Phil thesis, Kurukshetra University, Kurukshetra 2006.

Waston, A. 1993. Incidence and nature of sports injuries in Ireland Am. J. Sports Med., 21: $137-143$.

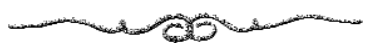

